\title{
PGR Gene
}

National Cancer Institute

\section{Source}

National Cancer Institute. PGR Gene. NCI Thesaurus. Code C28656.

This gene plays a role in the signal transduction processes that are involved in pregnancy. 